\title{
Macau in China's relations with the lusophone world
} Macau nas relações da China com o mundo lusófono

http://dx.doi.org/10.1590/0034-7329201400214

CARMEN AMADO MENDES*

Rev. Bras. Polít. Int. 57 (special edition): 225-242 [2014]

\section{Introduction}

The multi-cultural identity of Macau, shaped by the arrival of the Portuguese in the mid- $16^{\text {th }}$ century, inspired the Chinese enclave to embody the ideal of a bridge between East and West. After 500 years, the territory retroceded to the mainland but kept its Lusophone specificities, an instrument to Chinese overseas interests. Officially designated as a platform between China and the Lusophone world, Macau hides in the intermediary role that its unique characteristics allow it to play. Not a formal colony but rather a case of shared sovereignty, particularly noticeable during the Cultural Revolution incidents, the "territory under Portuguese administration" (Portuguese Constitution 1976, Arts. 5 and 306) was not included in the decolonization process, following instead the logic of retrocession through a negotiation process. ${ }^{1}$ The Minutes of Conversations on the Macau Question, signed in 1979 when Portugal and China resumed diplomatic relations, stated that the territory under Portuguese administration would be "handed-over to China..., when time is ripe, by the governments of the two countries through a negotiation process" (Minutes of Conversations and Joint Communiqué 1979). That would happen in the aftermath of the Sino-British negotiations on Hong Kong, resulting in the signature of the Macau Joint Declaration in 1987, which stated the transfer of Portuguese administration to the People's Republic of China in 1999 (Mendes 2013).

The Joint Declaration and the Basic Law of the Macau SAR - the "Constitution" of the enclave that entered into force when it was handed over to China, defined that during fifty years Macau "will enjoy a high degree of autonomy, except in

\footnotetext{
* University of Coimbra, International Relations, Coimbra, Portugal (carmen_mendes@hotmail.com).

1 The Special Administrative Regions of Macau and Hong Kong are special instances of decolonization or rather cases of retrocession because what was at stake was not their independence but their return to Mainland China. The negotiation processes for the Portuguese and British withdrawals did not take place between the metropolis and the colonies but between the metropolis and a third country, which was expected to assimilate the colonies. For more on the concept of retrocession see Mendes, 2014.
} 
foreign and defense affairs which are the responsibilities of the Central People's Government." However, autonomy regarding external relations is treated in a hybrid way in the two documents, which assume that

the Macao Special Administrative Region may on its own, using the name "Macao, China," maintain and develop relations and conclude and implement agreements with states, regions and relevant international or regional organizations in the appropriate fields, such as the economy, trade, finance, shipping, communications, tourism, culture, science and technology and sports. (Macau Joint Declaration, 1987, Annex I, Chap. VIII; and Macau Basic Law, 1993, Chap. VII - Domestic Affairs, Art. 136).

This openness, the maintenance of its Lusophone characteristics and the acceptance of Portuguese as one of the official languages along with Chinese, gave the Macau SAR the external autonomy required to develop an intense relationship, namely high-level, with the Portuguese ex-colonies. The good relationship between Lisbon and Beijing - the result of friendly Sino-Portuguese negotiations-and between Lisbon and its ex-colonies, facilitated the process. Soon after the Forum for Economic and Trade Cooperation between China and the Portuguese-speaking Countries was created in 2003, its Permanent Secretariat was based in the Macau SAR. Therefore, it is known as the Macau Forum, giving to this Special Administrative Region the role of a platform in connecting Beijing with the Lusophone world. The next sections will analyze whether this platform delivers concrete results or is merely a symbol of Macau's identity.

\section{Lusophony in Macau}

The symbolism that involves the Macau Forum is only understandable when acknowledging the Macau SAR as a point of encounter of the Lusophone culture. This is the result of the colonial architectural legacy and language, details negotiated during Sino-Portuguese negotiations, but also of the support to the Portuguese language and Lusophone events by the Chinese administration. The growing demand for Portuguese language courses transformed Macau into a privileged place of linguistic and cultural training for Chinese diplomats, interpreters and businessmen, before they start working in the Portuguese-speaking countries. Regarding the events, the first Lusophony Games took place in Macau in 2006, a place considered "unique" by the organizers, who aimed at creating

a common platform to sport, established together by countries and regions of Portuguese Official Language. [...] Participants from all over the world gathered for the first time around a unique element—one language, the Portuguese language. [...] It is the first time that such a sport event of this kind has the language as a common element. (Macau Sport Development Board 2013). 
The Lusofonia (Lusophone) Festival, created in 1998, continued to be organized every year in October, to promote the culture of the Portuguesespeaking countries and "honor the lusophone communities living in Macau, for their contribution in the development of the region" (IACM 2013). This traditional party, organized by the Institute for Civic and Municipal Affairs and the Tourist Office, includes several cultural activities, such as gastronomy, handicraft, exhibitions and concerts. The event, that usually lasted one weekend, gained a new dimension with the involvement of the Macau Forum in the organization of the "Cultural Week of China and Portuguese Speaking Countries." (Macau Forum 2013)

Several events have been organized in the Macau SAR, often with the support of the Macau Forum, with the official aim of "reinforcing cooperation between lusophony and China," namely international conferences gathering professionals from all Portuguese-speaking countries working in several sectors: medicine, journalism, law, and even in central banks, airports and civil engineer laboratories. Profiting from the attractiveness that has been linking Macau with lusophony, the University of Macau hosted several meetings of the Association of Universities of Portuguese Language-Associação das Universidades de Lingua Portuguesa (AULP): the $13^{\text {th }}$ was on the Lusophone space of high education and research, in 2003; the $16^{\text {th }}$ was on the organization of the landscape of high education and research in the Portuguese-speaking countries, in 2006, at the time of the second Ministerial Conference of the Macau Forum; and the $20^{\text {th }}$ was on "China, Macau and the Portuguese Speaking Countries" in 2010, the year of the Forum's third Ministerial Conference (AULP 2013).

The department of Portuguese of the University of Macau also hosted the World Symposium on Portuguese Language Studies in 2011, and organizes every year the Day of the Portuguese Language and the Summer Course on Portuguese Language and Culture. As this course includes visits and meetings with Macau officials, it contributes to informing participants about the role of Macau as a "meeting point between cultures and a platform to the relationship between China and the Portuguese-speaking countries" (Dias 2012). In the same line, in 2011 the University of Saint Joseph organized an international conference on lusophony and cultural encounters (Ponto Final 2011) and the Macau Polytechnic Institute hosted the meeting of the International Association of Lusophony Conferences, which principles and aims state:

Our definition of Lusophony will always be a dialogue in that secular language, including the eight Portuguese official language countries and its correspondent cultural identities, as well as all regions in which the Portuguese language is also used as mother tongue... (AICL 2013)

Ignoring the criticism regarding the manipulation of the scientific discourse to validate lusophony (Nascimento 2007) common among some political and 
intellectual elites of the Portuguese-speaking countries, the Macau government and institutions have exploited the concept to promote the image of Macau. Highlighting the space that the concept has conquered in the Chinese administration, the Macau Magazine, published by the government Press Office every three months, includes a section on Lusophony, as mentioned by its editor in 2005:

Another dimension highlighted is the role of the Macau SAR as a platform for cooperation between China and the Portuguese-speaking countries. [...] The Magazine will be distributed in all countries of Portuguese official language, in such a systematic and broad way as possible, without forgetting, of course, its readers from the MSAR. Being the Magazine so connected with lusophony, this edition also highlights another subject that is in the cover of this issue: the Portuguese language. [...] It is the wish of the "Macau [Magazine]" to deepen the relationship with $[\ldots]$ the generality of Portuguese language readers, from Macau to Brazil, without forgetting East Timor, Portugal and the lusophone African countries. (Ortet 2005, 1).

The International Institute of Macau also acknowledges the role of Macau as a point of exchange with the Lusophone world in several issues on Lusophony of the magazine East and West (IIM 2005, 4). The contribution of the Institute to this debate is noticeable through other publications such as two edited books on China's relations with the Portuguese-speaking countries (Sá 2009, 2011) and through the amount and diversity of events organized not only in Macau, but also in Portugal and Brazil.

The Macau Association for the Promotion of Exchange between Asia-Pacific and Latin America (MAPEAL) also considers that "different from Hong Kong and other Chinese cities, through its own historical process of more than four centuries Macau created its unique cultural identity, which can be called as Sino-Latin." Thus, it became the ideal base to reinforce relations and "reduce the distance between China and the lusophone world in economic and cultural terms." (Ngai 2004, 5) The president of this Association has argued that, on the one hand, "the Portuguese language is vital to maintain Macau's political and legal culture" and, on the other hand, it is important to invest in research and debate on the identity and model of Macau, for instance through the coordination between different research institutes within and outside of Macau. He considers the Forum for Economic and Trade Cooperation between China and the Portuguese Speaking Countries as "the first step to reinforce the role of Macau as a special bridge between China and the world Latin community" but that "it is not enough. It is a governmental institution with limited resources. We need to have more people working on these topics, not only in business but also in culture." (Ngai 2004, 10-11, 14)

In the business area, the International Lusophone Markets Business Association-Associação Comercial Internacional para os Mercados Lusófonos (ACIML) —organizes activities to bring together Chinese and Lusophone 
businessmen, counting with the participation of relevant businessmen and governmental entities. One of the sections of its magazine News of the Platform and its website focus on Lusophony (ACIML 2013). Furthermore, the last editions of the Macau International Fair (MIF), organized by the Macau Trade and Investment Promotion Institute (IPIM), included a common stand for the Portuguese-speaking countries (MIF 2013).

This brief description suggests how Lusophony is perceived as one way of reinforcing Macau's cultural model, giving an important contribution to the construction of its identity. Opposite to what was expectable during the last years of Portuguese administration, the protection of the Lusophone legacy is supported by Beijing: the cultural and linguistic system of the Macau SAR, similar to the Portuguese-speaking countries, reinforced its role of a bridge to the Lusophone world (Cardoso and Mendes 2002, 137-138). While in the two or three years immediately after the handover the colonial legacy was not welcomed, the status of the Portuguese language and culture was upgraded with the support of the central government in using Macau as a symbol of trans-regional integration between China and the Lusophone world. This Chinese manipulation of Lusophony is even more interesting considering the fact that the concept is used very carefully in Portugal as it is connected with colonialism in the Portuguese-speaking world. ${ }^{2}$

The feeling of belonging to the Lusophone culture is reflected in the facility of integration that citizens of the Portuguese-speaking countries have in Macau. The Macau government welcomes and supports associations of friendship from all Portuguese-speaking countries, including San Tome and Principe (that has diplomatic relations with Taiwan). These associations organize exhibitions and events, such as the celebration of their national days, and participate enthusiastically in the Lusophony Festival. Macau is the only Chinese region where Lusophone people can spend the whole day "in Portuguese": there is Portuguese television, radio, newspapers, bookstores, conferences, restaurants and cafes, and even the street names and maps are bilingual. The following section will analyze how these linguistic and cultural specificities help Macau to claim a crucial role in promoting economic and trade exchanges between China and the Lusophone world.

\section{The Macau Forum}

The official website of the Forum for Economic and Trade Cooperation between China and the Portuguese Speaking Countries states that: "The Forum will be mainly Portuguese-speaking countries, Angola, Brazil, Cape Verde, Guinea Bissau, East Timor, Mozambique, Portugal and the People's Republic of

2 This conceptual debate does not mean the rejection of the Lusophone culture by the ex-colonies, including those that were at war with Portugal for thirteen years. This is probably due to two main reasons: the delay in self-determination is connected with the dictatorship that lasted until 1974, and not with the Portuguese people; and citizens from ex-colonies feel welcomed and integrated in the Portuguese society. 
China"3 (Macau Forum 2013). Created in the Chinese Ministry of Commerce (MOFCOM), the Forum has different characteristics from other forums created by Beijing, ${ }^{4}$ namely the institutionalization of daily relations among member states, through a support mechanism:

Ministers agreed to establish a support mechanism, through the creation of a permanent secretariat in Macau that can guarantee the logistic and financial support, as well as the connection to materialize initiatives and implement projects (Macau Forum 2003).

The Permanent Secretariat is based in Macau, which is not a member of the Forum but a Region of one of the members (China) and shares with the other countries the legacy of the Portuguese colonial administration, the language and some cultural and administrative aspects. Thus, according to the International Institute of Macau, the Forum

gave back to Macau the multi-continental dimension that it had during centuries, in the relations with Africa, Latin America and Southeast Asia. Macau has again a unique role in China's relations with the Portuguese-speaking countries. This instrument is an important complement and a framework where China materializes relations at a multilateral level that complements the inter-governmental bilateral relationship. It gives an international identity to Macau, as a platform between China and the Portuguese-speaking countries, fulfilling the will of the central government, that launched this initiative, and of the local population and authorities (EastWest 2010, 25).

The structure of the Permanent Secretariat of the Forum includes: one Secretary-General, the formal leader of the Forum, appointed by Beijing; three Deputy Secretary-Generals; one delegate from each Portuguese-speaking country and their ambassadors in Beijing. The three Deputy Secretary-Generals include one from $\mathrm{China}^{5}$, one from Macau and the third one is chosen in a rotational basis by alphabetic order among the Portuguese-speaking countries. Each of them coordinates the three offices of the Permanent Secretariat: the Administration Office, in charge of the daily work of the Secretariat-China; the Support Office, that provides financial, administrative and logistical resources to the activities of the Secretariat-Macau; and the Liaison Office, which coordinates contacts between the Forum and its member states-Portuguese-speaking countries (Macau Forum 2008).

3 San Tome and Principe is not a member of the Forum because it has diplomatic relations with Taiwan; however, it is invited as observer to the Ministerial Conferences.

4 Cf. Forum of China-Africa Cooperation (FOCAC), 2000; Boao Forum for Asia (BFA), 2002; Shanghai Cooperation Organization (SCO), 2001; Sino-Arab Cooperation Forum (SACF), 2004; China Arab States Trade and Economic Cooperation Forum (CASCF), 2010; China-Pacific Island Countries Economic Development and Cooperation Forum (CPICEDCF), 2006.

5 This post has not been fulfilled probably because China is already represented by the Secretary-General. 
Portuguese-speaking countries' delegates that represent member states in this mechanism coordinate with the "focal points" in their countries, i.e., officials in charge of receiving and disseminating information on the Forum received by the Permanent Secretariat, in coordination with the Embassy in Beijing and some sectors at the national level. In the case of Angola, Brazil and Mozambique, the focal points are officials from the Asia department of the Foreign Ministry. In Portugal, East Timor and Guinea-Bissau, they belong to the Ministry of Economy (although in Bissau originally the focal point belonged to the Foreign Ministry). In Cape Verde, the focal point is in the Cape Verde Investments, the government investment promotion agency.

The Macau Forum is a very specific way of trans-regional cooperation. It is not an international organization: the only permanent structure is the Secretariat and the Forum only exists during its Ministerial Conferences every three years, gathering high representatives from Member states. However, it is more than a forum, because the Permanent Secretariat allows the organization of regular initiatives, giving it a dynamic that it would not have if it was limited to the Ministerial Conferences. This hybrid situation has been reinforced by the absence of a legal statute for the Permanent Secretariat, avoiding that delegates enjoy diplomatic status, even when they are diplomats. In the third Ministerial Conference, as a result of pressure by the Portuguese-speaking countries, a decision was taken, although it has not been applied yet:

Ministers reiterated that, in order to implement actions adopted in the $3^{\text {rd }}$ ministerial conference it is necessary to continue to improve the organic structure and functions of the permanent secretariat and, in this sense, asked for the intensification of the communication between the secretariat and the group of the heads of missions of the Portuguese-speaking countries in Beijing as a privileged mechanism towards harmonization, as well recommended to give the permanent secretariat of the Macau Forum a legal status in the Macau Special Administrative Region. (Macau Forum 2010).

The issue of the legal status of the Permanent Secretariat of the Macau Forum and the diplomatic status of its delegates would probably be solved if the Secretariat was based in mainland China instead of a Special Administrative Region with no formal autonomy in its external relations. Different reasons may be appointed to this resistance offered by China and Macau to give a legal existence to the Secretariat. On the one hand, this could lead the Forum to evolve towards an international organization, which would have a strong political connotation: it would give the Macau SAR a formal role in foreign policy, challenging the limited autonomy in external affairs stipulated by the Joint Declaration and the Basic Law. On the other hand, it is easier to allow the presence of San Tome and Principe as observer in this kind of forum than in a more formal structure. The presence of representatives of San Tome in the Ministerial Conferences interests Beijing, 
attracting their leaders to change recognition from Taipei. ${ }^{6}$ Their presence would be far more complicated from the political point of view if the Forum evolved in juridical terms.

In reality, there was always an attempt to disguise the Forum's political intentions and that is one of the reasons why it was framed in the Chinese Ministry of Commerce and not in the Foreign Ministry, as happened with the Forum on China-Africa Cooperation (FOCAC), created in 2000 (FOCAC 2005). The Macau Forum emerged as

a mechanism of cooperation of official initiative without political nature, which key topic is cooperation and economic development and aims to reinforce cooperation and economic exchanges between the People's Republic of China and the Portuguese-speaking Countries, to improve the role of Macau as a platform to those countries and to promote the development of links between the People's Republic of China, Macau and the Portuguese-speaking Countries. (Macau Forum 2013).

However, even not formally acknowledged, the political dimension of this "economic and commercial" forum is particularly evident during the Ministerial Conferences, high-level meetings that take place in Macau in autumn every three years: 2003, 2006, 2010 and 2013. ${ }^{7}$ One of the functions of the Ministerial Conferences in Macau is to approve the Action Plan for the three following years, previously negotiated in purely diplomatic terms in Beijing, between the committee of ambassadors of the Portuguese-speaking countries and staff of the Chinese Ministry of Commerce. The formulation of the Plan into specific activities is decided every year in March, during the ordinary meetings of the Permanent Secretariat with representatives from the three offices, the Portuguese-speaking countries' focal points and their ambassadors in Beijing. Afterwards, the Secretariat is in charge of implementing decisions, as it is the organ that works in Macau on a daily basis.

The role of platform "in strengthening economic and commercial cooperation between China and the Portuguese-speaking countries" that is given to Macau includes three main dimensions:

[...] cooperation between the companies from Macau, mainland China and the Portuguese-speaking countries in the joint development of several ways of cooperation in the areas of trade, logistics, investment, agriculture, fishery, natural resources exploration, building of infra-structures, health and telecommunications.

6 In the last Ministerial Conference, São Tomé e Príncipe was represented by the Minister of Planning and Finance, Hélio Almeida.

7 The third Ministerial Conference was postponed to 2010 for two reasons: the delay in replacing the Secretary-General of the Macau Forum and to avoid coinciding with the 10th anniversary of the handover. 
[...] human resources training for Portuguese-speaking countries citizens [...], particularly in the areas of language, trade, tourism, finances and business and administrative management.

[...] creation of opportunities of traineeship in the Portuguese-speaking countries to the graduates and professionals from Macau with the aim of promoting training and improvement of the Portuguese-language knowledge. (Macau Forum 2010, Art. 14 - the role of Macau as a platform).

In the business area, cooperation includes "the organization, in a rotational basis, of the Businessmen Meeting for Economic and Commercial Cooperation between China and the Portuguese-speaking Countries" to "spread information on investment and business opportunities, promote reciprocal business visits and the participation of companies in exhibitions, fairs and business meetings to economic and commercial cooperation that take place in the member states of the Macau Forum" (Macau Forum 2010, Art. 3 - the role of Macau as a platform). Investment agencies of the host countries, coordinated with institutions from Macau and China in charge of promoting investment, organize business exchanges, facilitating bilateral negotiations on trade transactions and investment partnerships (Gama 2012).

The Macau Trade and Investment Promotion Institute, besides giving this kind of support to the business meetings, provides information and publications on its website and divulges initiatives of the Macau Forum (e.g. IPIM 2011) and organizes business trips with the Permanent Secretariat. These trips, financially supported by the Macau SAR government, are introduced in very attractive packages to businessmen, lawyers and other professionals from Macau and mainland China with interests in the Lusophone world. The Permanent Secretariat receives growing requests from Chinese businessmen, namely from the province of Guangdong (very close to Macau), to participate in the trips and to receive administrative and legal support to enter in those countries. Thus, the Forum seems to aspire to be perceived as a big chamber of commerce between China and the Portuguese-speaking countries in order to support Small and Medium Enterprises; big state companies enroll in direct negotiations and do not need to go through Macau.

Among the above-mentioned dimensions attributed to the platform, the training of human resources assumed greater importance as the Permanent Secretariat created a Training Center of the Macau Forum in 2011. The Macau SAR has been given an important contribution to this, not only through the financial support of the Lusophone staff that goes to Macau to receive training, but also through the organization of the courses, which usually take place at the University of Macau. Portuguese-speaking countries' technicians often attend training sessions in Macau in several areas proposed by their own governments according to their needs. During one of these courses, which was organized for 
professors, a "Colloquium on the Chinese and Portuguese Languages Education in China and in the Portuguese-speaking Countries," the Forum Secretary-General Chang Hexi declared that the role of Macau is to be a channel, not a protagonist:

Through the organization of this kind of colloquiums, all Portuguese-speaking countries can gather here in Macau and profit from this platform to exchange views, to improve education. [...] That is the role that a platform as Macau is playing (Chang 2012).

The training courses, which target Portuguese-speaking countries, are complemented with organized trips to Macau and China, contributing to create trust between both sides, facilitating the establishment of commercial links. Many of the Lusophone participants, after days of talks, banquets and touristic and business trips, return to their home countries attracted by the Chinese development model and with a feeling of familiarity regarding Macau. Macau's historical legacy of the Portuguese administration, the only cultural characteristic that China shares with the Lusophone world, along with its traditional role of a bridge between East and West, result in a familiar environment where leaders and businessmen from distant continents feel comfortable to negotiate, in a new way of regional cooperation between countries that originally had few affinities.

In the last Ministerial Conference, the Chinese Vice-Prime Minister Wang Yang announced that Beijing wishes to continue to use the Macau SAR as a platform from China to the Portuguese-speaking world, thus reinforcing the importance that former Prime Minister Wen Jiabao attached to this relationship in the Third Ministerial Conference in 2010. The creation in Macao of a trading service centre for SMEs, of a distribution centre for food products, and an exhibition and conference centre for Portuguese-speaking Countries, for which the Macau Secretary for Economy and Finances, Francis Tam, stated his commitment (Pimentel 2013) is another sign that the role of Macau as a platform will tend to be strengthened.

\section{Lusophone perceptions of the Forum}

The importance that the Portuguese-speaking countries give to the Macau Forum can be evaluated by the way they are represented at the Ministerial Conferences and in the Permanent Secretariat and its activities. Due to the absence of guidelines regarding representativeness, member states have different approaches regarding the choice of focal points and delegates of the Permanent Secretariat. The past Ministerial Conferences attained different levels. In the first and second Conferences, several ministers participated, especially ministers of economy, trade and foreign affairs; Brazil was strongly criticized for "only" sending a Secretary. ${ }^{8}$

8 Ivan Ramalho - Executive Secretary of the Ministry of Development, Industry and Foreign Trade. 
In the third Ministerial Conference, besides China that sent Premier Wen Jiabao, four other Member states were represented by heads of State or Government: President José Ramos Horta represented East Timor and Prime-Ministers Carlos Gomes Júnior, Aires Bonifácio Ali and José Sócrates were sent as representatives of Guinea-Bissau, Mozambique and Portugal. Cape-Verde sent a Secretary of State, Humberto Brito; Angola sent the Minister of Economy Abrahão Gourgel; and Brazil sent the Deputy-Minister of Foreign Affairs Carneiro de Mendonça (Macau Forum 2011, 4).

In the last Ministerial Conference, the countries represented at ministry level were: Angola, with its Minister of Justice and Human Rights, Rui Mangueira; Cape Verde, with its Minister of Tourism, Industry and Energy, Humberto Santos de Brito; and Mozambique, with its Minister of Foreign Affairs and Cooperation, Oldemiro Baloi. Brazil dispatched its Vice-President, Michel Temer, and Guinea Bissau its Prime Minister Rui Duarte Barros, while Portugal and East Timor were represented by their Vice-Prime Ministers: Paulo Portas and Fernando Araújo, respectively. As for China, the Minister of Commerce Gao Hucheng and the Vice-Prime Minister Wang Yang took part in the event.

These differences regarding the representative level often result from the domestic constraints of member states and not from the clear intention of dismissing the Ministerial Conference. However, if the national political context, for instance a campaign or election period, affects the level of participation, it means that the Macau Forum is not a priority for those member states.

Regarding the Liaison Office of the Permanent Secretariat, delegates are also selected according to criteria defined by their Governments, being thus affiliated to different ministries, usually foreign affairs, economy and trade. On the one hand, Angola, Cape Verde, Guinea-Bissau, Mozambique and East Timor have permanent delegates, although the one from Angola spends half of the day working at the Angola Consulate in Macau and the one from Mozambique often goes to Beijing to deal with bilateral issues. On the other hand, Brazil only sends its Consul in Hong Kong to Macau to attend the most relevant meetings. Portugal used to count on the local representative of the trade and investment agency-Agência para o Investimento e Comércio Externo de Portugal (AICEP) — to interact with the Permanent Secretariat, but attributed this task to the Consul in Macau just before the fourth Ministerial Conference. The different ways in which member states chose focal points and delegates suggests that some perceive the Macau Forum as a political institution, while for others it is an economic and commercial instrument or a mechanism of attracting investment.

This variety of approaches reflected in the criteria underlining the choice of participants, suggests that Portuguese-speaking countries have different expectations on the relevance that this Forum can have in their relationships with China. These different perceptions do not surprise Beijing: China also has different aims regarding the Macau Forum. The Lusophone world can be divided into two 
big groups according to their development stage, with Portugal and Brazil being the more developed and diversified economies. Due to the irrelevance of the trade balance with Portugal and strong, well established bilateral economic relations with Brazil, we can conclude that the Chinese target for the creation of the Macau Forum is the Lusophone Africa and East Timor (Alves 2008, 15; 2005, 1168).

In Lusophone Africa, leaders and officials that know the Macau Forum consider it complementary to the Forum on China-Africa Cooperation, which also organizes high-level meetings every three years. To Angola, Cape-Verde, Guinea-Bissau and Mozambique, the Macau Forum can facilitate negotiations and decision-making at the bilateral level and have more specific results than FOCAC for several reasons. First, the Macau Forum is more specific, belonging to the Chinese Ministry of Commerce and not to the Foreign Ministry, as FOCAC; while the Macau Forum is officially focused on economic and trade cooperation, FOCAC deals with different dimensions-political, economic, commercial, education and security (Xinhua 2006). Second, the Macau Forum only has eight members, not fifty. Third, the members of the Macau Forum are represented in Macau on a daily basis, sharing the same language and culture, which guarantees a closer relationship. Having said that, interviews revealed that China and the Lusophone countries mostly favor the bilateral channel. The reference to the development of economic and commercial relations "both at the bilateral level and at the multilateral level" in the Macau Forum Action Plans assumes that the aim is to reinforce bilateral interaction and not the creation of an alternative way of multilateral cooperation:

Ministers agreed in intensifying and improve the mechanism of bilateral consultation between China and the Portuguese-speaking Countries...

Ministers agreed that the mechanisms to be established in the framework of the Forum are complementary to the ones that already exist in bilateral consultations...

Ministers reiterated their engagement in the development of bilateral relations in the economic field... (Macau Forum 2003, 2006, 2010)

Findings from fieldwork in the member states of the Macau Forum suggest that the importance that the Portuguese-speaking countries give to the Forum and its events changes according to the state of their bilateral relations with China; and that their perceptions of the Chinese financial support to the Forum is influenced by their level of development and financial situation. Cape Verde, Guinea-Bissau, Mozambique and East Timor perceive the Forum as an important instrument to deepen bilateral cooperation with China, as they feel that in a group they may secure more advantages. These affinities between some Lusophone countries are particularly noticeable during the negotiations of the Action Plans in Beijing and the Programs of Activities of the Permanent Secretariat in Macau. Their perspective 
is to use the Forum as a channel to protect domestic interests, through the attraction of Chinese investment and training of ministerial staff, promoted by the Training Center of the Permanent Secretariat on critical areas. Interest to attract Chinese investment is growing in Portugal as well, in this context of crisis. Angola, due to its increasingly better financial situation and growing relations with China in the bilateral plan, does not mention the Macau Forum with the same enthusiasm: the Chinese presence, especially noticeable in the areas of infrastructures and natural resources, is negotiated by the elites of the two States, through the embassies, ministries, state companies and even at a personal level.

Brazil openly favors the bilateral relationship with China and even considers the Macau Forum as damaging to its interests as it reinforces the Chinese presence in Lusophone Africa. Brasilia and Beijing have symmetric bilateral relations, sharing the world stage reserved to emerging powers with the visibility that BRICS and G20 offer, and hold common world views regarding leadership in international institutions, challenging the current hierarchy of power in the international system. Partners in the international system, these two actors compete in Brazil's market, which imposes protectionist measures towards Chinese imports, and in Latin America and Africa, where Brazilian companies cannot compete with the financial packages offered by Chinese companies-especially in infrastructures.

Brazilian leaders are not willing to support an instrument that helps Chinese negotiators to gain space in areas of strategic interest to Brazil. This is the main reason for their antagonism to the creation of the Macau Forum and the lack of importance that they give to it, suggested by the way Brazil is represented and the engagement in the activities organized by the Permanent Secretariat: Brazil was never an active partner and is suspicious of the Forum. Brazilian ambassador Valdemar Neto in Beijing declared in July 2013 that

Macao, as a platform, only makes sense as an additional value to the existing channels of cooperation, considering that Brazil already has a strong connection to all the nations involved, in a wide range of areas. [...] it will be difficult to carry out the work, if the main purpose of the Forum is the promotion of Macao as a platform (Pimenta 2013, 13).

These comments were very much noted and criticisms led to a more cautious approach by Vice-President Michel Temer, the highest representative that Brazil ever sent to a Forum event. In his speech during the opening ceremony of the fourth Ministerial Conference last November he said: "I am sure that, to all of you that share the legacy of the Lusophone culture, coming to Macau evokes a look to the past and a vision to the future" (Temer 2013).

To sum up, the Macau Forum member states that have a stronger relationship with China are Portugal (historical and political), Brazil (political, economic and commercial) and Angola (economic and commercial). The fact that China's relations with these countries do not pass through Macau suggest that the Forum 
may not assume a crucial role in China's connection with the Lusophone world. However, and considering that international institutions do not disappear unless something exceptional happens, the Macau Forum does not seem to be at risk. On the contrary: its financial supporters-China and Macau—are the ones who are most interested in the existence of the Forum, with the strong support of some Portuguese-speaking countries. In the last Ministerial Conference, Vice-Premier Wang Yang announced eight new measures for the 2014-2016 Action Plan, mostly targeting African countries and East Timor, in order to contribute to the new goal set by China: that the volume in trade with the Portuguese-speaking Countries surpasses the US\$ 160 billion in 2016 (Wang 2013; Almeida 2013).

\section{Concluding remarks}

The Portuguese-speaking countries are not a homogeneous cultural, political and economic group, sharing identical characteristics and views of the world. On the contrary: it is a very heterogeneous group, even in terms of geography, landscape and behavior, including the command of the Portuguese language- the only common feature that justifies the concept of Lusophone world. It is therefore expectable that Beijing develops with them diverse bilateral relations and that their perceptions of the relevance of the Macau Forum are also different.

The role of the Macau SAR as a bridge between China and Lusophony is promoted by different institutions and governmental initiatives and by civil society, the most visible one being the Forum for Economic and Trade Cooperation between China and the Portuguese-speaking Countries. This Forum has unique characteristics that do not allow it to evolve to an international organization. In formal terms, the Forum ends with each Ministerial Conference, organized every three years, and does not have permanent structures besides the Secretariat. The Permanent Secretariat does not have legal status and is located in a Region that has no autonomy in international relations and is not member of the Forum-except in an indirect way, for being a Chinese Special Administrative Region. Moreover, the post of Secretary-General is always occupied by Beijing, which challenges the basic principles of multilateralism regarding equality and rotational leadership.

Therefore, the Macau Forum is not a multilateral institution but rather the institutionalization of China's bilateral relations with the other member states. In the Action Plans, in the section on intergovernmental cooperation, the multilateral dimension is always mentioned along with the bilateral one, without overlapping it. This gives member states legitimacy to put the Macau Forum second to bilateral channels. It also helps to explain that the importance that Portuguese-speaking countries attach to the Forum fluctuates according to the strength of their bilateral relations with China. The level of engagement in the Forum's activities and the evaluation of Macau's financial support also differ. For instance, in terms 
of attitude, not all delegates and focal points are very active in the Permanent Secretariat and in the ministries to which they belong.

The fact that the Forum is not a priority along with some constraints and the absence of a clear strategy in the choice of delegates and focal points, results in the appointment of some individuals without the required profile. ${ }^{9}$ Another issue is the financial support that delegates receive from the Support Office of the Permanent Secretariat. This support is welcomed by some countries but badly perceived by others, who are not happy with the dependency that this creates towards this Office, the Macau government and Beijing. Therefore, they chose not to have a delegate in the Permanent Secretariat. Other countries profit from Macau's location to charge their delegates of dealing with bilateral matters with Beijing. The lack of rules and uniformity in the modus operandi leads to the coexistence of different perspectives, highlighted for instance by the fact that focal points belong to different ministries in the Member States.

The decision-making process of the Forum is also unique, lacking definition on where economic and commercial cooperation ends and foreign policy begins. The Action Plan is negotiated within the Ministry of Commerce- the Forum is for "Economic and Trade Cooperation" so it does not belong to the Foreign Ministry. However, it is negotiated by the ambassadors of the Portuguese-speaking countries in Beijing, who receive instructions from their foreign ministries. Moreover, it is signed in the Ministerial Conference in Macau by the ministers that are in charge of the Forum, who belong to different ministries. Finally, the Action Plan results in yearly activity plans negotiated in the Permanent Secretariat by ambassadors, ministers, focal points and delegates, and it is implemented by delegates.

A forum with these specificities could only exist in the Macau Special Administrative Region, a unique enclave and the meeting point of Lusophone cultures within China, with a hybrid legal framework in foreign relations. China continues to implement the strategy defined by Portugal five hundred years ago, through the promotion of the Macau SAR as a unique platform in its relations with the Lusophone world, using its cultural and linguistic legacy while rejecting the negative connotation of colonial memories. In the intersection between East and West, Macau went through the Portuguese to the Chinese administration, but the importance of its intermediate role subsists. However, to present undeniable results as a platform, Macau needs to reinvent its role in the Forum and reform the Permanent Secretariat. Similarly, if the Portuguese-speaking countries want to enjoy substantial benefits from their membership, they should consider the Macau Forum a foreign policy priority.

9 One of the constraints is the difficulty in finding officials with good knowledge of the Portuguese language in all member states of the Forum, which is particularly noticeable in East Timor. This also affects the selection of participants in the training actions of the Forum in Macau, other than limiting the choice of delegates and focal points. 


\section{Bibliographic references}

ACIML - Associação Comercial Internacional para os Mercados Lusófonos [International Lusophone Markets Business Association] (2013). Novidades da Plataforma. In [http://www. aciml.org.mo/por/plataforma.htm]. Accessed: 28/11/2013.

AICL - Associação Internacional dos Colóquios da Lusofonia [International Association of Lusophony Conferences] (2013) in http://www.lusofonias.net. Accessed: 28/11/2013.

ALMEIDA, Fátima (2013). China lança medidas para ampliar cooperação [China launches new measures in order to extend cooperation], Jornal Tribuna de Macau, 6 November, p. 2.

ALVES, Ana (2005) Macau: uma Ponte entre a China e os Países Africanos de Língua Oficial Portuguesa [Macau: A Bridge between China and the Portuguese-speaking African Countries]. Administração, Vol. 18, no. 69, Macau, pp. 1163-1173.

ALVES, Ana (2008) China's Lusophone Connection. China in Africa, Report no. 2. Johannesburg: The South Institute of International Affairs, 33 p.

AULP - Associação das Universidades de Lingua Portuguesa [Association of Universities of Portuguese Language] (2013), in [http://aulp.org]. Accessed: 28/11/2013.

Basic Law of the Macau Special Administrative Region of People's Republic of China (1993). Beijing: 31 March.

CARDOSO, Daniel and MENDES, Carmen Amado (2012) Lusofonia em Macau: Que Contributos para o reforço das relações Sino-Brasileiras? [Lusophony in Macau: What Contribution to strengthening Sino-Brazilian relations?] in Pretov, Petar et al. (eds.), Avanços em Comparatismos nas Lusofonias. Santiago de Compostela-Faro: Associação Internacional de Lusitanistas, Através Editora, pp. 133-150.

CHANG, Hexi (2012). Ensino de português e chinês deve ter mais qualidade [The teaching of Portuguese and Chinese should have more quality], interviewed by Maria Caetano, Ponto Final, Macau, 14 August.

DIAS, Aldino (2012) UM Celebra 'Dia da Língua Portuguesa'. [The University of Macau celebrates the Day of the Portuguese Language] Jornal Tribuna de Macau, 23 February.

EastWest (2010). Macau International Institute, no. 23, January, p. 25.

FOCAC (2005). Forum on China-Africa Cooperation [http://www.focac.org/eng/] Accessed in $20 / 12 / 2012$.

GAMA, Joaquim (2012). O Fórum de Macau [The Macau Forum], International Conference on the Portuguese in the International Organizations. Luanda: 4 July 2012.

IACM - Civic and Municipal Affairs Bureau (2013). 15 Festival da Lusofonia, 4a Semana Cultural da China e dos Países de Língua Portuguesa $\left[15^{\text {th }}\right.$ Lusophony Festival, $4^{\text {th }}$ Cultural Week of China and the Portuguese-speaking Countries]. Government of the Macau Special Administrative Region, published in IACM [http://www.iacm.gov.mo]. Accessed: 28/11/2013.

IIM - Instituto Internacional de Macau [Macau International Institute] (2005) OrienteOcidente, no. 15 , July, p. 4.

IPIM - Macau Trade and Investment Promotion Institute (2011). Macau Image, no.53, January. Joint communiqué on the resumption of Sino-Portuguese diplomatic relations (1979). Paris: 8 February 1979. 
Joint Declaration of the Government of the People's Republic of China and the Government of the Republic of Portugal on the Question of Macau (1987). Beijing: 13 April.

Macau Forum - Forum for Economic and Trade Cooperation between China and the Portuguese-speaking Countries (2003). Action Plan for Economic and Trade Cooperation. Macau, 13 October.

Macau Forum (2006). Action Plan for Economic and Trade Cooperation. Macau, 25 September. Macau Forum (2010). Action Plan for Economic and Trade Cooperation. Macau, 14 November.

Macau Forum (2008) Regulamento de Funcionamento do Secretariado Permanente do Fórum para a Cooperação Económica e Comercial entre a China e os Países de Língua Portuguesa. 10 March.

Macau Forum (2011) Boletim Trimestral. Permanent Secretariat of the Forum, no. 16-17.

Macau Forum (2013), in [http://www.forumchinaplp.org.mo/pt]. Accessed: 28/11/2013.

Macau Sport Development Board (2006) Os Jogos da Lusofonia [The Lusophony Games]. Government of the Macau Special Administrative Region no. 2, 2006.

Macau Sport Development Board (2013). Government of the Macau Special Administrative Region, published in <http://www.sport.gov.mo/pt>. Accessed: 24/9/2012.

MENDES, Carmen Amado, (2013a) Portugal, China and the Macau Negotiations, 1986-1999. Hong Kong: Hong Kong University Press, 172 p.

MENDES, Carmen Amado (2013b) A Relevância do Fórum Macau: O Fórum para a Cooperação Económica e Comercial entre a China e os Países de Língua Portuguesa [The Importance of the Macau Forum: The Forum for Economic and Trade Cooperation between China and the Portuguese-speaking Countries]. Nação e Defesa, no. 134. Lisboa: Instituto da Defesa Nacional, p. 279-296.

MENDES, Carmen Amado (2013c) Macau 500 Anos Depois: A Plataforma da China para o Mundo Lusófono [Macau 500 years later: China's platform for the Portuguese-speaking World]. Revista Oriente, no. 22, 2013. Lisboa: Fundação Oriente, p. 44-59.

MENDES, Carmen Amado (2014). The Implications of the Special Administrative Regions for the International System: Macau as a successful case study. In Wei, George (ed.), Macao: The Formation of a Global City, New York: Routledge, p. 208-221.

MIF - Macau Internacional Trade \& Investment Fair (2013), Macau Trade and Investment Promotion Institute in [http://www.mif.com.mo]. Accessed: 28/11/2013.

Minutes of Conversations on the Macau Question (1979). Paris, 8 February 1979.

NASCIMENTO, Augusto (2007) A Lusofonia para além dos afectos e dos adornos: as premissas de um (possível) saber partilhado [Lusophony beyond the affections and ornaments: the premises of a (possible) shared knowledge]. Relaçôes Internacionais, no. 15, September. Lisbon: IPRI, p. 125-132.

NGAI, Gary (2004) Macau an ideal base to develop Sino-Latin ties. OrienteOcidente, 13 May, p. 5, 10-11, 14 .

ORTET, Luís (2005). Editorial, published in Revista Macau, no. 1, December, p. 1.

PIMENTA, João (2013). Fórum Macau deve servir países africanos e Timor-Leste [Macau Forum should serve African countries and East Timor], Jornal Tribuna de Macau, 7 July, p. 13. 
PIMENTEL, Sandra (2013). New energies' pleases everyone: Chinese Minister of Commerce Underlined the Scope of the Action Plan, Jornal Tribuna de Macau, 6 November, p. 4.

Ponto Final (2011), Macau, 22 February.

Portuguese Constitution (1976). Coimbra: Atlântida Editora, Arts. 5 and 306.

SÁ, Gonçalo César (coord.) (2009) Macau e as Relações Económicas China / Países de Língua Portuguesa - dez anos de crescimento 1999-2009. Macau: Macau International Institute.

SÁ, Gonçalo César (coord.) (2011) À descoberta da China e dos países lusófonos: Macau: potencialidades turísticas e estratégias promocionais. Macau: Macau International Institute.

TEMER, Michel (2013) Foro de Macau - Pronunciamento do Senhor Vice-Presidente da República na Cerimónia de Abertura [Macau Forum - Speech of Mr. Vice-President of the Republic in the Opening Cerimony]. Macau, 5 November.

WANG Yang (2013) Wang Yang announces eight new measures to support the development of Portuguese-speaking Countries. Portal of the Government of the Special Administrative Region of Macao, 5 November [http://portal.gov.mo/web/guest/info_detail?infoid=277631] Accessed: 28/11/2013.

Xinhua (2006). FOCAC exhibition showcases China-Africa cooperation. China View [http:// news.xinhuanet.com/english/2006-11/03/content_5287030.htm] Accessed: 15/4/2013.

Submitted December 2, 2013

Accepted February 5, 2014

\section{Abstract}

After the transfer of the Portuguese administration to China, Macau kept its role as a bridge between East and West, inspired in the Portuguese settlement 500 years ago. The pragmatism of the Chinese central government, using the Lusophone specificities of this Special Administrative Region, supported the creation of the Forum for Economic and Trade Cooperation between China and the Portuguese-speaking Countries, reviving the statute of the Portuguese language and culture in its own territory.

Keywords: China; Macau; lusophony; Portuguese-speaking countries.

\section{Resumo}

Depois da transferência da administração portuguesa para a China em 1999, Macau manteve o seu papel de ponte entre o Oriente e o Ocidente, inspirado pela chegada dos portugueses 500 anos atrás. O pragmatismo do Governo Central chinês na utilização das especificidades lusófonas desta Região Administrativa Especial permitiu a criação do Fórum de Cooperação Económica e Comercial entre a China e os Países de Língua Portuguesa, reavivando o estatuto da língua e cultura portuguesas no seu próprio território.

Palavras-chave: China; Macau; lusofonia; países de língua portuguesa. 